\title{
THE TYLER PHOTOGRAPHS OF IOWA MILITARY MEN.
}

By LOREN S. TYLeR.

THE COLLECTING.

My last three months' service was as clerk in the tents of the Adjutant's regiment, May-July, 1865. I have never been relieved from that duty. ${ }^{1}$ Often with another clerk, I worked on reports and returns, fifteen to twenty hours a day, to complete the rolls and books, many hours under guard to prevent us from stealing away to obtain some long-needed rest. Especially the last weeks' in July, while the other three regiments of our brigade had left Louisville for Towa, the veterans of the Fifteenth were clamoring to 'be mustered out and sent home.

We arrived in Davenport in August and I returned to my home in Keokuk, Iowa. Soon after, Generals H. T. Reid, William W. Belknap and John M. Hedrick, former colonels of the Fifteenth, insisted that General George Pomutz, who had commanded the regiment the last year of its service, was the man to comply with the resolution adopted by the General Assembly of the State of Iowa, approved February 23, 1864,

\footnotetext{
${ }^{1}$ When any man or number of men were desired from the ranks for special duty, they were ordered out. After performance of the special duty they were relieved from that order and the duty it entailed. With some fifteen other men I was detailed from the Fifteenth Infantry as an adjutant's clerk just as the war was closing. Most of them had been or soon were to be commissioned officers in their own or other regiments. At the very end of the service of the Fifteenth only one other and myself remained. We two were left without commissions although I was, on June 6,1878 , commissioned Major and Assistant Inspector General, First Brigade, First Division Iowa National Guards, serving until June 12, 1881. On August 5, 1865, my Company, $H$, and the clerks from Company $G$ were paid near midnight and their discharges given them. $A$ dozen boys piled into a covered wagon at the barracks at Davenport and rode down to the hotel "Live and Let Live," and about two o'clock got to bed. The Quartermaster had turned over all the government property he was responsible for, also the men who had guarded it, and the wagoner and ambulance driver had been relieved and rejoined their companies. But the Adjutant's clerks worked on until it was reported by a man from Company $G$ that that Company was being paid off, then the other clerk rushed from the office leaving me alone. Shortly a boy came and said our company was being paid off and the captain had sent for me. So I scooted for the Company and the greenbacks. Of course a strict compliance with the regulations would have required the Adjutant to have relieved us two clerks, but he was busy packing up. So was every one else, and rushing away to catch the next train or boat for home, so we did not stand a minute waiting to be relieved, we just skipped.
} 
and prepare a history of our regiment. It seemed natural when toward the end of August General Pomutz called me to report, and I entered upon another three months' service. General Belknap wrote of General Pomutz:

He had a military education in Hungary, was exiled, and came to America in 1848, and settled in New Buda, Iowa. He was appointed Adjutant of the regiment on its formation. As an office adjutant he had no superior. Methodical beyond example in his regimental papers, he kept a descriptive book of the regiment, giving the service of every officer and man, which is historically accurate and which is surpassed by no regimental record in the War Department.

For three months General Pomutz and I labored with several chests full of papers and reports of the past four years. He had been a very successful collector, and during those years no order, circular, or paper of any importance came into the regimental headquarters, but he had a copy made. He retained them for his personal use, with copies of every order issued by superior headquarters, every report and return required by the State, the Army Regulations, or the War Department. Therefore, he had an abundant supply of official matter.

Excepting the original rolls of the regiment, and those of the veterans, recruits, and casualties, the result of his labor of love for his old regiment can be found in Adjutant General N. B. Baker's report, Jan. 1, 1865, to Jan. 1, 1866, pages 197-271.

In General Pomutz's farewell order to the Fifteenth, given on page 267 , he stated that arduous campaigns had called for the best settled habits of discipline, which he strictly enforced, and that it was deemed all important to have the deficiencies of former years, the papers, records, and books of the command completed, so as to save the interests of the Government, and at the same time to do full justice to each and all who had ever been connected with the regiment. He trusted that as the records stand they might prove a real benefit in future to all of the members of the regiment, from its first organization. 
Under his eye and training, it was obvious that I should absorb some of his pride in keing thorough in work and in the records of our regiment. I believe that while so engaged, the collection germ stung me, and the sting is still at work, for during his absence, for a Garibaldi, ${ }^{2}$ I copied several diagrams he had made of battle-fields, sieges, and picket lines while in the service. From then on, especially after the formation of Crocker's Iowa Brigade Association at Washington, Iowa, September 28 and 29, 1881, I gathered in, or collected, everything - relating to my company, regiment, brigade, division, corps and the Army of the Tennessee and their commanders.

At our third brigade reunion at Iowa City, September 24, 1885 , our regiment swarmed. I made a motion that we organize the Fifteenth Iowa Veteran Association. It carried unanimously, as did motions to elect historians for the Field and Staff and each company, and to publish a regimental history.

My company, H., elected me its historian and I began to feel that I was still on duty. The regiment elected General W. W. Belknap the second colonel and General J. M. Hedrick the third, to be regimental historians, and take entire charge of preparation and publication of the history.

They, knowing I had not been relieved from duty away back in 1865 , commanded me still, and ordered me to compile the regimental history. Orders were orders, especially when issued by two generals, even for extra and continuous duty.

The history prepared by General George Pomutz in the fall of 1865 was the foundation upon which: we built, and the compilation was completed while I resided in Salem, Mass., and sent to General Belknap at Washington, D. C., in May, 1887. A few days later he ordered me there, to help him cut the mass of manuscript in two. After my arrival and an hour's talk about the copy of legal cap, seventeen inches

\footnotetext{
${ }^{2}$ As a remedy for flux Pomutz brewed what he called Garibaldi tea. It was in short, hot tea, brown sugar and whisky. Capt. J. M. Reid, History of Company " $I$ " in History of the 15th Regiment Iowa Veteran Volunteer Infantry.-Tyler.
} 
thick, he had promised to revise, he decided we would not chop anything out, and said, "Let er go Gallagher," but later changed it to "Vota Vita Mea" on the title page. ${ }^{3}$ The history was revised by General Belknap, and he, with Colonel William H. Gibbon and Major Mortimer A. Higley advanced the required funds to publish the work, which made a large octavo of 644 pages.

General H. V. Boynton of Ohio, wrote, "It is a marvel of historical regimental detail, and it makes the blood run quick and hot to turn it through." The National Tribune of Washington, D. C., said: "It is of marvelous detail in connection with the rolls of the regiment, the services of its members, the rolls of casualties, and of the deaths, and survivors and their residences since the war. In its detailed work as a regimental history it is without a rival."

Ninety-two commissioned officers served in the Fifteenth Regiment, Iowa Infantry. Several of their portraits were in

\author{
3History \\ of the Fifteenth Regiment \\ Iowa Veteran \\ Volunteer Infantry \\ from \\ October, 1861, to August, 1865 \\ When disbanded at end of the war. \\ Vota Vita Mea \\ Keokuk. \\ R. B. Ogden and Son, print., 1887.
}

The Preface is:

This History of the Fifteenth Iowa Volunteer Infantry, claims for itself no literary merit. It is defective in many points, but the compiler and reviser, and the officers of the Regimental Association are free from blame.' Circulars have been sent to all of the members, and if any of the Company Histories are deficient in matter and reminiscence, the criticism, if any, must fall where it belongs.

Upon the death of the beloved General Hedrick, whose heart was in the history, the undersigned was requested by Major Higley, the Vice President, and Major McArthur, the Secretary of the Association, to revise the work.

Having been the Colonel of the Regiment, and its Brigade Commander for so long a time, this labor has been a most delicate one, for reasons obvious to all.

Others have kindly written what has been said personal to himself, and what he has written as to others. has been done. he believes impartially and truthfully. He has personally written the history of the. Field and Staff, not including that portion referring to himself.

The labor of the work has been done by Mr. Loren S. Tyler, formerly of Company $\mathrm{H}$, who was selected as compiler, and all will admit that it has been well done. The rolls and lists of casualties, and all the records involving great and anxious care, have been examined, and the History prepared by General Pomutz, re-examined, corrected and copied by Mr. Tyler.

He deserves and will have the thanks of the Regiment.

He and $I$ are aware of its defects, but send it to the Regiment as a record of their camps, marches and battles, in which the service of officers and men will do them honor forever.-WM. W. BELKNaP. 
the history, and I had others, and I thought a complete set would make a valued second volume. On March 6, 1888, I began a search for the ninety-two portraits, those taken in uniform and during war time preferred.

I wrote to Major M. A. Higley, President of our Regimental Association, requesting the loan of any photographs of our officers he had, so that I could have copies made.

That splendid officer had such confidence in every man who had served in the Fifteenth Iowa, that six days later I received from him twenty-two A 1 fine photographs, taken when the pure chemicals used made them permanent, by Emerson at Keokuk, while the Fifteenth was being recruited and in rendezvous in that eity, in the winter of 1861-2.

Here on my first requisition came one-fourth the number required to fill the quota, and naturally I felt highly elated.

Then a Corporal's guard of five arrived in two squads by March 26th, followed on the 28th, by an end of the war time company of twenty, ${ }^{4}$ from my life-long comrade and old commander, Major H. C. McArthur of Company H., continuing that esprit de corps that made him famous in two days, viz: in the bloody charge of July 21st and the Giant of Battles on July 22d, 1864, before Atlanta, two days in which our regiment lost two hundred and fourteen, or over fifty-six per cent of the three hundred and eighty men in line and where in the charge of the Twenty-first Major McArthur received a piece of shell in his right thigh, a mighty ugly wound, and was carried to the Division Hospital. But next day, the $22 \mathrm{~d}$, the rebel bullets, shot and shell fell thick and fast around and through the hospital, and all therein were ordered to hustle out. The firing continued heavy. Soon McArthur's friends pushed him down on top of a dead soldier in a newly dug grave for security. During a lull in the battle they "tried to tote the grave to the rear for better protection."

\footnotetext{
The companies at enlistment usually numbered a hundred men. "Toward the end of the war the decimation suffered often left but the
} 
On March 28th, after the Atlanta campaign, came a second company of twenty photographs, from that ever-ready soldier, Captain S. Rynearson, Company C., who was one of fourteen comrades enlisting as privates in the Fifteenth and who later became captains of companies by solid worth.

In eighteen days from five good friends I had borrowed seventy-two of their highly-treasured portraits. This made all but twenty that I needed, and it seemed as though at the end of another month I should gather them in.

Then my hopes were shattered by receiving a letter from Captain Farnham, of Chicago, saying that he had been hunting over eight years for photographs of the fifty-eight of his (an Illinois) regiment, and had not yet secured them all, but wished me success.

I hammered away, however, receiving eighteen photographs in nine days in April; fourteen others in May; fourteen more in June, making one hundred and eighteen in my three months' hunt. Many were duplicates so the search continued for just eleven months, and my correspondence extended from Massachusetts through all the States to California, Arizona, Texas and Maryland.

Thirty good friends in ten States and two Territories sent ' me one hundred and thirty-five photographs. I had my quota filled and I rejoiced.

Some collections grow on one and cause one to have a collecting germ which also grows continuously. The first one I made of our ninety-two regimental officers' portraits was complete, with their ninety-two photographs. There could be no more and no less. It was finished. It seemed to be a second wolume to the Fifteenth Iowa's history, making that more complete and valuable. But the germ was working right along, day and night.

I soon found a third volume could be annexed to our history, by adding to the portraits of several of our officers which I possessed, those of enlisted men who had been promoted, commissioned and served in twenty-seven other commands. This required several months' time. After a while I located 
the last portrait and that quota, and the third volume of the History of the Fifteenth Iowa Veteran Infantry, was completed. I had the satisfaction of knowing that I was then the only one of the regiment, and the only man in the entire United States or on earth who possessed that History in three volumes.

Of course, I could have started after material for a fourth and even a fifth volume, by collecting photographs of all the sergeants, corporals, drummers, and bummers, and all the other good enlisted men of the regiment, over seventeen hundred all told, and by writing just a little about what I knew of the aggregate, and of the individuals, it would have made a grand collection. But I was laboring with other matters, so for many reasons halted.

I had our seven regimental, and was assembling portraits of the twelve brigade, fourteen division, and seven corps commanders; of Generals Grant, Sherman, McPherson, Logan, and Howard, the commanders of the never-beaten Army of the Tennessiee.

While thus engaged I was discovered by James E. Taylor of New York City, who served three years in the Tenth New York Infantry and later was an artist for Frank Leslie's illustrated paper, in the field. He made the original sketch of the famous Grand Review in Washington, D. C., May 23, 1865 , eopies of which are to be found today in every town in the United States. He was the greatest collector of portraits of generals in the United States. He collected over five thousand and sold them to Gunther of Chicago. Our acquaintance soon proved to our mutual advantage, he sending me portraits I needed, and I securing for him many that he had for years sought in vain. In time, my collection of portraits of our forty-five commanders was complete, but I was still affected with the collecting bug.

One day in looking over General N. B. Baker's roster of officers in his report for 1867, I checked off two hundred and eight names of Iowans who were commissioned colonels of her regiments during the war. 
It struck me that their portraits would be a unique collection. A short search proved I could add fifty to those I already had, and with the addresses of the colonels and many more members of Iowa regiments I decided to enter another campaign.

It was not long before I had over one hundred of these portraits; some steel engravings, but mostly photographs, and the majority of them taken in uniform and during the war.

During my search, I came across a book, then another, then a good many, such as Heitman's "Historical Register of the U. S. Army from 1789 to 1889." Wading through a hundred years of rosters is no small task, but going on, I became interested. Soon I found a name of an Iowa colonel, who was not entered in any of General Baker's most excellent reports because he had not been commissioned in ạ Iowa regiment. After a while I came to the end of those one hundred years in that book. Other books on war subjects, campaigns, battles, generals, regiments, etc., etc., came into my hands, resulting now and then in augmenting General Baker's roster of 208 to 220 , to 230 , and 250 , and as the roster increased, I realized that my task and likewise my correspondence had, also.

The task grew more difficult on account of deaths, removals, and all manner of changes, during the years since 1861. It grew more and more difficult to get into communication with a colonel or his relatives, or a brother officer or a comrade possessing a desired likeness. Many replied that they once had the desired photographs but fire had destroyed them. The days and months passed on, and the years of search resulted in annexing eighty-nine more names to General Baker's roster of two hundred and eight Iowa colonels, a total of two hundred and ninety-seven colonels and lieutenant colonels, full rank and by brevet.

While the roster had increased beyond all my expectations so had the work. I was spurred on to renewed action by receiving from time to time much encouragement. I was greatly indebted to General William W. Belknap, late Secretary of War, General John W. Noble, late Secretary of the Interior, 
General Thaddeus H. Stanton, late Paymaster General U. S. Army, Colonel Cyrus C. Carpenter, and Captain Buren R. Sherman, ex-governor of Iowa, all heroic soldiers, and to eighty other splendid Iowans, who became generals or colonels by long-continued and distinguished services, who so kindly sent me their portraits, their compliments and best wishes for my success in the undertaking.

I had known for years that Colonel Ed. W. Lucas, Fourteenth Iowa Infantry, resided in Iowa City. I had met and had several chats with him in Des Moines, while he was a member of the General Assembly, and in his home city where one day he pulled me down upon his knees and talked for a helf hour.

Each time I met him, he promised by the beard of Mahomet to send me his photo. But he never did, and it was some months after his death before I received from a friend in his city his portrait, which completed the collection.

During my long hunt, I received one hundred and sixtyseven autograph letters from generals and colonels and many others from distinguished men. Over four hundred letters were received from other officers and soldiers, wives, widows, mothers, fathers, daughters, sons, sisters, brothers, friends and many good live comrades, who took deep interest in my work and promptly assisted me in many ways to procure longed for portraits. They came from Maine and Washington Territory; from New Hampshire and Oregon; from Massachusetts and California; from New York and Florida; from Rhode Island and Texas, from thirty-three States, the Indian, New Mexico and Wyoming Territories, and the District of Columbia. To the writers of them, one and all, I send my most grateful and sincere acknowledgments.

I expect there will be people who will say that on Tyler's roster there are names of men, who were not Iowa soldiers. Right here, I wish to emphasize the fact that my roster of the two hundred and ninety-seven Iowans who entered the United States service, and attained the rank of lieutenant 
colonel during the Civil war of $1861-1866,{ }^{5}$ is absolutely correct, and supported by the Official Records of the Government. And, as "Linkensale" wrote of the Grand Review in 1865, "Crocker's Iowa Brigade made the finest appearance in the whole column, not less than twenty miles in length, and I will maintain that assertion against all comers, devoutly leaving the decision to the day of judgment."

Many names on the roster will not be recognized today by even the oldest residents of Iowa. For example, who will remember that old warrior, "befo' de wah"-_Samuel Ross, of Dubuque? He was Private, Corporal, Sergeant, and Commissary Sergeant, Company A., Eighth United States Infantry, 1837-1840 ; Private, Corporal, 1st Sergeant, Battery B, Second U. S. Artillery, 1841-1846 ; Private, Corporal, Sergeant, and 1st Sergeant, Company H., Fifteenth U. S. Infantry, 1846, Mexican War; Brevet 2nd Lieutenant, Third U. S. Infantry, resigned, 1849 ; Captain Fourteenth U. S. Infantry, 1861; Colonel Twentieth Connecticut Infantry, 1862-3. Brevet Major, Lieutenant Colonel and Colonel U. S. Army, Brevet Brigadier General U. S. Volunteers, 1865; Major Twenty-eighth U. S. Infantry. Retired with rank of Brigadier General United States Army, 1871. Accidentally drowned in Osceola Lake, Westchester county, New York, July 11, 1880.

Another was Francis Markoe Cummins of Muscatine, Captain Company A. First Iowa Infantry, three months' service; 1st Lieutenant Colonel Sixth Iowa Infantry. On Sunday, at Shiloh, "He came up to me," says Lieut. J. Monroe Reid,

${ }^{5}$ I have until recently stated that the War Department officially decided that the Civil war began April 5, 1861, and ended May 1, 1865 . In 1895 the United States Supreme Court decided that the civil war ended August 20,1866 . But $I$ am in receipt of the following:

"War Department, The Adjutant-General's Office,

Respectfully returned to Washington, June 29, 1912 .

Mr. Loren S. Tyler,

710 Kingsley Drive, Los Angeles, Cal.

The dates of beginning and ending of the Civil War, as officially deter. mined by the Supreme Court of the United States, are set forth in the case of "The Protector." It was held by the Court in that case that the Civil War did not begin or close at the same time in all the states. The case referred to is reported in Volume 12 of Wallace's reports, page 700 . That publication can no doubt be consulted in almost any law library. 
Company I., Fifteenth Iowa," "armed with a musket, his fiery-red face begrimed with powder, and knowing him well I asked what he was doing there.' His answer was, 'I am under arrest and hunting a place to fight.' I answered, 'Here's the place! Glad to have you, Colonel!' He loaded' and fired and stayed with us until the last." After leaving the Sixth Iowa, he went east and later was commissioned Lientenant Colonel of the 124th New York Infantry at Gettysburg. He was severely wounded. His colonel being killed, he was promoted colonel and served through the war. $\mathrm{He}$. died at Goshen, New York, March 26, 1884.

With the two hundred and ninety-seven portraits of Iowa's generals and colonels I have sent to the State Historical Department those of all the eleven captains of her batteries of light artillery. . Ninety-two negatives including every officer of the Fifteenth Iowa, twenty-three negatives of the enlisted men of the Fifteenth promoted and commissioned in other regiments-in all one hundred and fifteen; and one hundred and seventeen negatives of colonels and six of the captains, a total of two hundred and thirty-eight negatives of Towa's soldiers.

As soon as possible, I shall send sketches of the military services of each colonel, compiled from official reports, and the one hundred and sixty-seven or more autograph letters, and over four hundred other letters from officers, men, and relatives, heretofore mentioned, with many pamphlets, and one thousand two hundred and forty-two feet of clippings relating to officers and men and their commands during and since the war. All will go to the Historical Department of Iowa, and with them my most earnest hope that they will prove to be of great interest and assistance to the coming generations of the State, where "Our liberties we prize and our rights we will maintain." The whole to be forever identified as "The Loren S. Tyler Collection" as my esteemed friend, the Curator of the Historical Department of Iowa, has suggested.

'History 15 th Iowa, Ibia p. 83. 


\section{THE COLLECTION.}

The collection, now the property of the State Historical Department of Iowa embraces the portrait of every citizen of the State who attained the rank of Lieutenant Colonel, full rank or by brevet, or of Captain of a Battery of Light Artillery, in his service in the War of the Rebellion.

FIRST IOWA CAVALRY.

Col. Fitz Henry Warren................. Steel engraving

Col. James Otis Gower..................Photograph

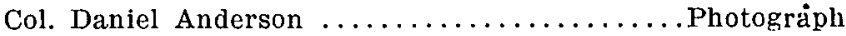

Col. William Thompson ................. Photograph

Lieut. Col. Charles E. Moss............. Photograph

Lieut. Col. P. Gad Bryan................ Photograph

Lieut. Col. Joseph W. Caldwell............. Photograph

Lieut. Col. Alexander G. McQueen............ Photograph

Bvt. Lieut. Col. James D. Jenks............ Photograph

Bvt. Lieut. Col. John MeDermott ............ Photograph

SECOND IOWA CAVALRY.

Col. Washington L. Elliott.............2 Photographs

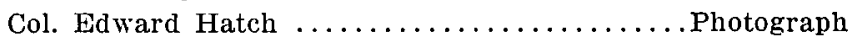

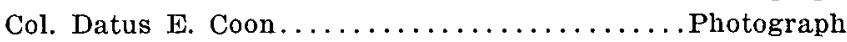

Lieut. Col. William P. Hepburn............ Photograph

Lieut. Col. Charles C. Horton.............. Photograph

THIRD IOWA CAVALRY.

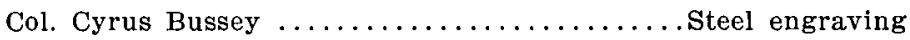

Col. Henry C. Caldwell.................. Steel engraving

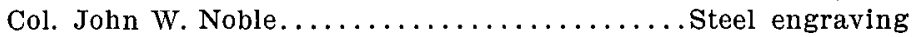

Lieut. Col. Henry H. Trimble............. Steel engraving

Lieut. Col. Benjamin S. Jones.............Photograph

Lieut. Col. George Duffield ............. Photograph

FOURTH IOWA CAVALRY.

Col. Asbury B. Porter.................. Photograph

Col. Edward F. Winslow................ Steel engraving

Lieut. Col. Thomas Drummond ............ Photograph

Lieut. Col. Simeon D. Swan...............Photograph

Lieut. Col. John H. Peters...............Photograph

FIFTH IOWA CAVALRY.

Col. William W. Lowe....................Photograph

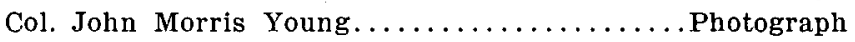

SIXTH IOWA CAVALRY.

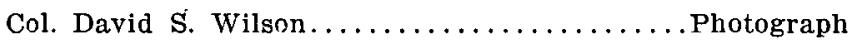

Col. Samuel M. Pollock................Photograph 
SIXTH IOWA CAVALRY-CONTINOED

Lieut. Col. Edward P. TenBroeck............. Photograph

Bvt. Col. DeWitt C. Cram...................Photograph

SEVENTH IOWA CAVALRY.

Col. Samuel W. Summers...................Photograph

Col. Herman H. Heath................... Photograph

Lieut. Col. John Pattee..................... Photograph

Bvt. Col. George M. O'Brien.................. Photograph

Bvt. Col. James B. David.................. Photograph

Bvt. Lieut. Col. Andrew J. Willey.............. Photograph

Bvt. Lieut. Col. Harrison W. Cremer........... Photograph

Capt. Andrew J. Millard...................Photograph Sioux City Independent Co. Cav.

Later 1 Co., 7th Iowa Cav.

EIGHTH IOWA CAVALRY.

Col. Joseph B. Dorr......................Photograph

Col. Horatio G. Barner................... Photograph

Lieut. Col. Elliott Shurtz.................Photograph

NINTH IOWA CAVALRY.

Col. Matthew M. Trumbull..................Photograph

Lieut. Col. John P. Knight.................Photograph

Bvt. Col. Edgar T. Ensign...................Photograph

FIRST BATTERY, IOWA LIGHT ARTILLERY.

Capt. Charles H. Fletcher..................Photograph

Capt. Junius A. Jones................... Photograph

Capt. Henry H. Griffiths.................. Photograph

Capt. William H. Gay...................Photograph

SECOND BATTERY, IOWA LIGHT ARTILLERY.

Capt. Nelson T. Spoor...................Photograph

Capt. Joseph R. Reed.....................Photograph

Capt. John W. Coons....................Photograph

THIRD BATTERY, IOWA LIGHT ARTILLERY.

Capt. Mortimer M. Hayden...................Photograph

Capt. Melville C. Wright...................Photograph

Capt. Orlo H. Lyon.................... Photograph

FOURTH BATTERY, IOWA LIGHT ARTILLERY.

Capt. Philip H. Goode...................Photograph

FIRST IOWA INFANTRY.

Col. John F. Bates...................... Photograph

Lieut. Col. William H. Merritt...............Photograph 


\section{SECOND IOWA INFANTRY.}

Col. Samuel R. Curtis.......................... engraving Major-General Curtis and Staff.

Maj. Gen. Samuel R. Curtis.

Brig. Gen. Clinton B. Fisk.

Brig. Gen. Norton P. Chipman.

Brig. Gen. Thomas I. McKenney.

Brig. Gen. John W. Noble.

Col. John G. Lee.

Capt. F. S. Winslow.

Capt. - Alpheldt.

Lieut. - - Stark.

Col. James M. Tuttle.................. Steel engraving

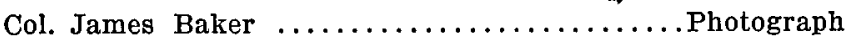

Col. Noah W. Mills................... Steel engraving

Col. James B. Weaver................. Steel engraving

Lieut. Col. Henry R. Cowles...............Photograph

SECOND AND THIRD IOWA INFANTRY CONSOLIDATED.

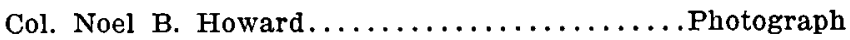

Lieut. Col. George L. Wright............. Photograph

Lieut. Col. Charles W. Gurney............. Photograph

\section{THIRD IOWA INFANTRY.}

Col. Nelson G. Williams............... Photograph

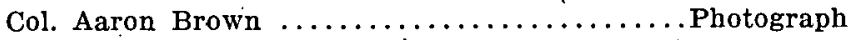

Lieut. Col. James Tullis.................. Photograph

Also a group of Col. Aaron Brown and Major

George W. Crosley.

Lieut. Col. Jacob Abernethy .............Photograph

FOURTH IOWA INFANTRY.

Col. Grenville M. Dodge................. Steel engraving

Col. James A. Williamson................ Photograph

Col. Samuel D. Nichols................. Photograph

Lieut. Col. John Galligan ............... Photograph

Lieut. Col. George Burton ................ Photograph

Lieut. Col. Albert R. Anderson............. Photograph

FIF'TH IOWA INFANTRY.

Col. William H. Worthington............ Photograph

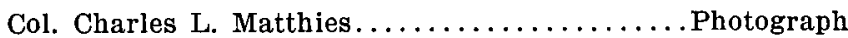

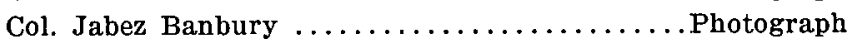

Lieut. Col. Ezekiel s. Sampson............. Photograph 
SIXTH IOWA INFANTRY.

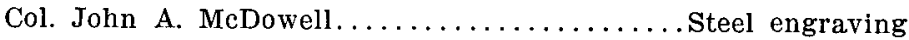
Photograph

Col. John M. Corse. Steel engraving

Col. William H. Clune Photograph

Lieut. Col. Francis M. Cummins............. Photograph

Lieut. Col. Alexander J. Miller.............. Photograph SEVENTH IOWA INFANTRY.

Col. Jacob G. Lauman................ Photograph

Col. Elliott W. Rice.................... Steel engraving

Col. James C. Parrott................... Photograph

Lieut. Col. Augustus Wentz ............. Photograph .

Lieut. Col. Samuel Mahon ............... Photograph

Bvt. Lieut. Col. Joseph B. Morrison........... Photograph

EIGHTH IOWA INFANTRY.

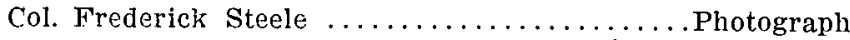

Col. James L. Gedies................... Photograph

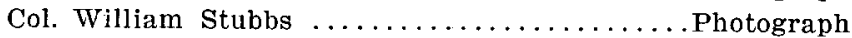

Lieut. Col. John C. Ferguson............... Photograph

Lieut. Col. William B. Bell............... Photograph

Lieut. Col. Andrew Geddes .............. Photograph

NINTH IOWA INFANTRY.

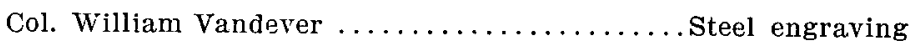

Col. David Carskaddon ................ Photograph

Lieut. Col. Frank G. Herron.............. Steel engraving

Lieut. Col. William H. Coyl..............Photograph

Col. William Vandever, Lieut. Col. Francis J.

Herron, Major William H. Coyle..........Photograph

Lieut. Col. Alonzo Abernethy.............. Photograph TENTH IOWA INFANTRY.

Col. Nicholas Perczel]. .................. Photograph

Col. William E. Small................... Photograph

Col. Paris P. Henderson................ Photograph

Lieut. Col. William H. Silsby ............. Photograph

Lieut. Col. Aaron W. Drew............... Photograph

ELEVENTH IOWA INFANTRY.

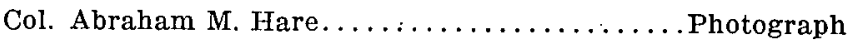

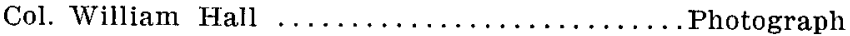

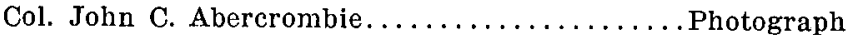

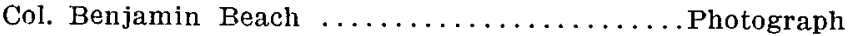

Lieut. Col. John C. Marven............... Photograph

TWELFTH IOWA INFANTRY.

.Col. Joseph J. Woods, W. P. R. A........... Photograph

Col. John W. Stibbs.................... Photograph 


\section{TWELFTH IOWA INFANTRY-CONTINUED}

Lieut. Col. John P. Coulter.............. Photograph

Lieut. Col. Samuel R. Edgington............ Photograph

Lieut. Col. Samuel G. Knee.............. Photograph

THIRTEENTH IOWA INFANTRY.

Col. Marcellus M. Crocker............... Steel engraving

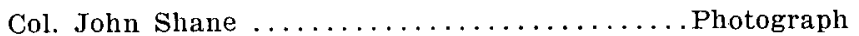

Col. James Wilson ................... Photograph

Lieut. Col. Milton M. Price................ Steel engraving

Lieut. Col. Justin C. Kennedy............. Photograph

FOURTEENTH IOWA INFANTRY.

Col. William T. Shaw................. Photograph

Lieut. Col. Edward W. Lucas............... Photograph

Lieut. Col. Joseph H. Newbold.............. Photograph

Lieut. Col. Warren C. Jones.............. Photographs As Captain and one as a Southern Planter.

Bvt. Col. George M. Staples............... Photograph

FIFTEENTH IOWA INFANTRY.

Col. Hugh T. Reid.................... Photograph

Col. William W. Belknap................Photograph

Col. John M. Hedrick.................. Photograph

Lieut. Col. George Pomutz ................ Photograph

Bvt. Lieut. Col. James S. Porter............ Photograph

Bvt. Lieut. Col. William H. Gibbon..........Photograph

Bvt. Lieut. Col. James M. Reid.............Photograph

SIXTEEN'TH IOWA INFANTRY.

Col. Alexander Chambers, W. P. R. A......... Photograph

Col. Josiah T. Herbert................ Photograph

Lieut. Col. Addison K. Sanders.............Photograph

Lieut. Col. John Henry Smith............ Photograph

Lieut. Col. Peter Miller ................. Photograph

SEVENTEENTH IOWA INFANTRY.

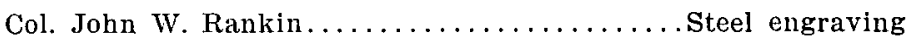

Col. David B. Hillis................... Photograph

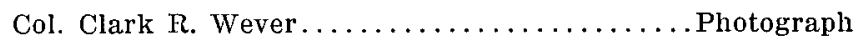

Col. Sampson M. Archer................. Photograph

Lieut. Col. William Horner ............... Photograph

EIGHTEENTH IOWA INFANTRY.

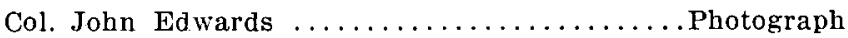

Col. Hugh J. Campbell................ Steel engraving

Lieut. Col. Thomas F. Cook.............. Photograph

Lieut. Col. Joseph K. Morey............... Photograph 
NINETEENTH IOWA INFANTRY.

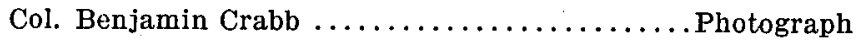

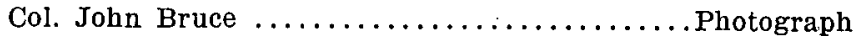

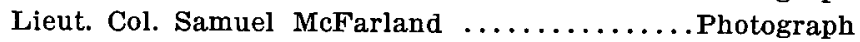

Lieut. Col. Daniel Kent ................. Photograph

Lieut. Col. Harry Jordan .............. Photograph

TWENTIETH IOWA INFANTRY.

Col. William McE. Dye, W. P. R. A........... Photograph

Lieut. Col. Joseph B. Leake..............Photograph

Bvt. Lieut. Col. Abram o. Blanding........... Photograph

TWENTY-FIRST IOWA INFANTRY.

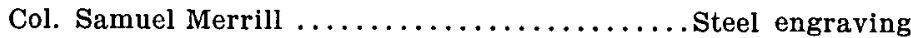

Lieut. Col. Cornelius W. Dunlap............. Photograph

Lieut. Col. Salue G. Van Anda............. Photograph

TWENTY-SECOND IOWA INFANTRY.

Col. William M. Stone.................. Steel engraving

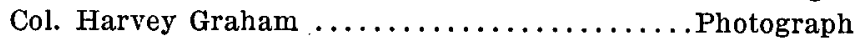

Lieut. Col. Ephraim G. White.............Photograph

TWENTY-THIRD IOWA INFANTRY.

Col. William Dewey .................. Photograph

Col. William H. Kinsman..............2 Photographs One standing, one sitting.

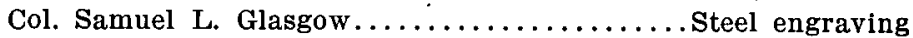

Lieut. Col. Charles J. Clark............... Photograph

TWENTY-FOURTH IOWA INFANTRY.

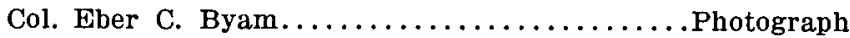

Col. John Q. Wilds................... Photograph

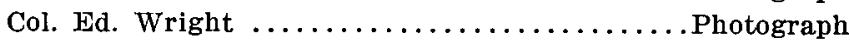

Lieut. Col. Leander Clark................ Photograph

TWENTY-FIFTH IOWA INFANTRY.

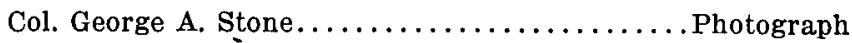

Lieut. Col. Fabian Brydolf ............... Photograph

Lieut. Col. David J. Palmer..............Photograph

TWENTY-SIXTH IOWA INFANTRY.

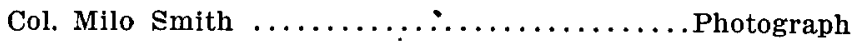

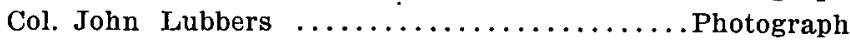

Lieut. Col. Samuel G. Magill..............Photograph

Lieut. Col. Thomas G. Ferreby..............Photograph

Lieut. Col. Nathan D. Hubbard..............Photograph 
TWENTY-SEVENTH IOWA INFANTRY.

Col. James I. Gilbert................ Photograph

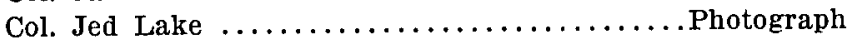

Lieut. Col. George W. Howard............. Photograph

TWENTY-EIGHTH IOWA INFANTRY.

Col. William E. Miller.................Photograph

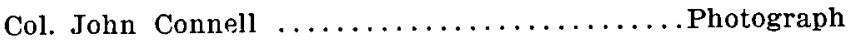

Col. Bartholomew W. Wilson............. Photograph

Lieut. Col. John Meyer................. Photograph

TWENTY-NINTH IOWA INFANTRY.

Col. Thomas H. Benton, Jr.............. Steel engraving

Lieut. Col. Robert F. Patterson.............Photograph

THIRTIETH IOWA INFANTRY.

Col. Charles H. Abbott................ Photograph

Col. William M. G. Torrence............. Photographs

Lieut. Col. Aurelius Roberts..............Photograph

THIRTY-FIRST IOWA INFANTRY.

Col. William smyth ................. Photograph

Col. Jeremiah W. Jenkins............... Photograph

Lieut. Col. Theodore Stimming............. Photograph

THIRTY-SECOND IOWA INFANTRY.

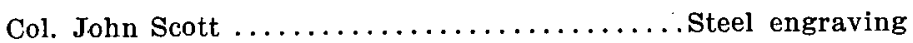

Col. Gustavus A. Eberhart.............. Photograph

Lieut. Col. Edward H. Mix............... Photograph

Lieut. Col. Jonathan Hutchison ............ Photograph

THIRTY-THIRD IOWA INFANTRY.

Col. Samuel A. Rice.................. Steel engraving

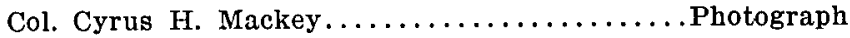

Lieut. Col. John Lofland ................. Photograph

THIRTY-FOURTH IOWA INFANTRY.

Col. George $\mathrm{W}$. Clark................. Steel engraving

Lieut. Col. Warren S. Dungan............. Photograph

Bvt. Lieut. Col. Victor H. Coffman............ Steel engraving

THIRTY-FIFTH IOWA INFANTRY.

Col. Sylvester G. Hill. ................ Photograph

Lieut. Col. James H. Rothrock............. Photograph

Lieut. Col. William B. Keeler............2 Photographs

Bvt. Lieut. Col. William Dill.............. Photograph 
THIRTY-SIXTH IOWA INFANTRY.

Col. Charles W. Kittredge................ Steel engraving

Lieut. Col. Francis M. Drake............... Photograph

THIRTY-SÉVENTH IOWA INFANTRY.

Col. George W. Kincaid...............2 Photographs

Lieut. Col. George R. West..............Photograph

THIRTY-EIGHTH IOWA INHANTRY.

Col. D. Henry Hughes................. Photograph

Lieut. Col. Joseph O. Hudnutt............. Photograph

THIRTY-NINTH IOWA INFANTRY.

Col. Henry J. B. Cummings............... Photograph

Col. Joseph M. Griffiths................ Photograph

Lieut. Col. James Redfield ............... Photograph

Lieut. Col. George N. Elliott............. Photograph

FORTIETH IOWA INFANTRY.

Col. John A. Garrett................... Steel engraving

Lieut. Col. Samuel F. Cooper............. Photograph

FORTY-FIRST IOWA INFANTRY BATTALION.

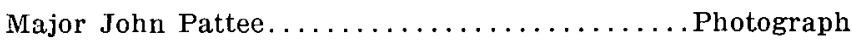

FORTY-SECOND AND FORTY-THIRD IOWA REGIMENTS.

(Did not complete their organizations.)

FORTY-FOURTH IOWA INFANTRY.

Col. Stephen H. Henderson................. Photograph

Lieut. Col. Henry Egbert..............2 Photographs

FORTY-FIFTH IOWA INFANTRY.

Col. Alvah H. Bereman............... Photograph

Lieut. Col. Samuel A. Moore.............. Photograph

FORTY-SIXTH IOWA INFANTRY.

Col. David B. Henderson................ Photograph

Lieut. Col. Lorenzo D. Durbin............. Photograph FORTY-SEVENTH IOWA INFANTRY.

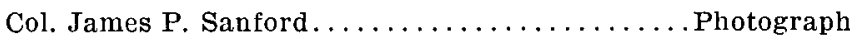

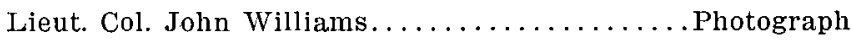

FOR'TY-EIGHTH IOWA INFANTRY BATTALION.

Lieut. Col. Oliver H. P. Scott............. Photograph 
IOWANS WHO WERE COLONELS OR LIEUTENANT COLONELS OF REGIMENTS FROM OTHER STATES.

FIRST ALABAMA CAVALRY.

Col. George E. Spencer................ Photograph

Lieut. Col. George L. Godfrey.............. Photograph TWENTIETH CONNECTICUT INFANTRY.

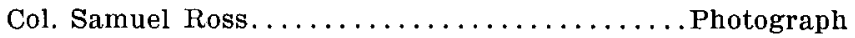
ONE HUNDRED TWEN'TY-EIGHTH INDIANA INFANTRY.

Lieut. Col. Richard K. Miller.............. Photograph THIRTEENTH KANSAS INFANTRY.

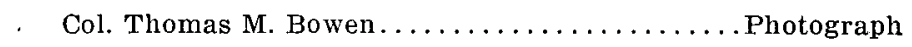
FIRST MISSOURI ENGINEERS.

Lieut. Col. William Tweeddale............. Photograph FIRST NORTHEAST MISSOURI INFANTRY.

Lieut. Col. Jesse H. Holmes.............. Photograph TENTH MISSOURI INFANTRY.

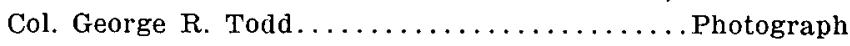

ELEVENTH PENNSYLVANIA CAVALRY.

Col. Franklin A. Stratton......1 Photograph, 1 Steel engraving SIXTH REGIMENT, VETERAN RESERVE CORPS.

Lieut. Col. Frederick S. Palmer............. Photograph

SIXTH REGIMENT, U. S. VOLUNTEER INFANTRY.

Lieut. Col. William W. Smith............. Photograph

U. S. COLORED TROOPS.

SECOND AND THIRD U. S. C. HEAVY ARTILLERY.

Lieut. Col. James P. Harper..............Photograph FORTY-SEVENTH U. S. C. INFANTRY.

Col. Hiram Scofield.................. Photograph FIFTY-THIRD U. S. C. INFANTRY.

Lieut. Col. Charles E. Compton............ Photograph FIFTY-FIFTH U. S. C. INFANTRY.

Col. James M. Irvin................ Photograph 
FIFTY-SIXTH U: S. C. INFANTRY.

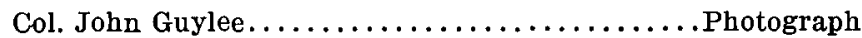

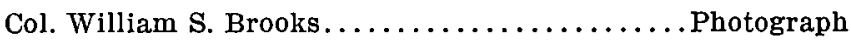

FIFTY-SEVENTH U. S. C. INFANTRY.

Lieut. Col. Philander J. Harrington...........Photograph

FIRST IOWA A. D. SIXTIETH U. S. C. INFANTRY.

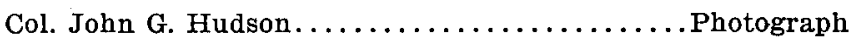

- Lieut. Col. Milton F. Collins...............Photograph

Lieut. Col. Gardiner A. A. Deane............ Photograph

SIXTY-FIRST U. S. C. INFANTRY.

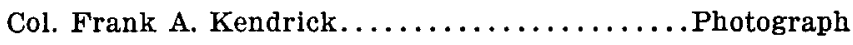

SIXTY-THIRD U. S. C: INFANTRY.

Lieut. Col. Albion L. Mitchell.............Photograph

SIXTY-EIGHTH U. S. C. INFANTRY. •

Lieut. Col. James H. Clendenning. .......... Photograph

SEVENTIETH U. S. C. INFANTRY.

Col. Willard. C. Earle.................Photograph

NINETY-EIGHTH U. S. C. INFANTRY.

Lieut. Col. Samuel G. Guernsey............ Photograph

ONE HUNDRED SEVENTH U. S. C. INFANTRY.

Lieut. Col. David M. Sells................ Photograph

ONE HUNDRED THIRTEENTH U. S. C. INFANTRY.

Col. Lauriston W. Whipple..............2 Photographs

ONE HUNDRED THIRTY-SIXTH U. S. C. INFANTRY.

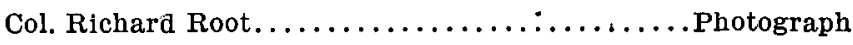

ONE HUNDRED THIRTY-EIGHTH U. S. C. INFANTRY.

Lieut. Col. George Curkendall............. Photograph

GENERALS.

Bvt. Maj. Gen. William T. Clark...........Photograph

Bvt. Maj. Gen. Thomas J. McKean............ Photograph

Bvt. Maj. Gen. Benjamin S. Roberts, W. P. R. A. Steel engraving

Bvt. Brig. Gen. Norton P. Chipman..........2 Photographs

Bvt. Brig. Gen. William Hyde Clark........... Photograph

Bvt. Brig. Gen. Thomas I. McKenney.......... Photograph

Bvt. Brig. Gen. David Remick............. Photograph

Bvt. Brig. Gen, Verplanck Van Antwerp........ Photograph 
STAFF.

Lieut. Col. and A. D. C. Peter Todd Hudson...... Photograph Lieut. Col. and Chief Com. Sub. 13th Army Corps,

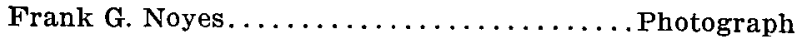

Lieut. Col. and Com. Sub. Vols. Egbert T. S.

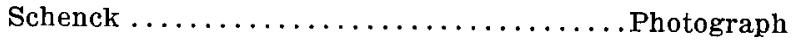

Lieut. Col. and Chief Qr. Mr. Army of Cumber-

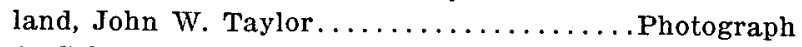

Lieut. Col. and Asst. Insptr. Gen. U. S. Vols.,

Charles W. Asmussen................ Photograph

\section{BREVET COLONELS, U. S. VOLUNTEERS.}

Col. Cornelius Cadle.................. Photograph

Col. Chief Con. Sub. 16th and 15th Army Corps,

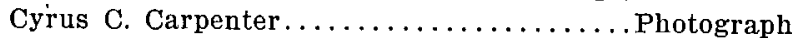

Col. Hancock's Vet. Corps, George W. Crosley... Photograph

Col. Evarts S. Ewing.................. Photograph

Col. and A. D. C. George E. Ford............ Photograph

Col. and A. D. C. George C. Tichenor.......... Photograph

Col. and Com. Sub. James VenDeventer......... Photograph

Col. and Addtl. Paymaster U. S. Vols. John F.

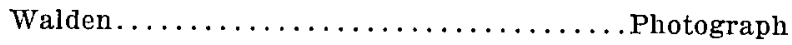

BREVET LIEUTENANT COLONELS, U. S. VOLUNTEERS.

Major and Addtl. Paymaster William Allen..... Photograph

Major and Surg. Medical Director, 17th Army

Corps, James H. Boucher.............. Photograph

Major and Paymaster U. S. Vols. Jesse Bowen... Photograph Major and Addtl. Paymaster U. S. Vols. Frank

Bridgman...................... Photograph

Capt. and A. D. C. Vols Hugh G. Brown........ Photograph

Major and Surg. U. S. Vols. Seymour D. Car-

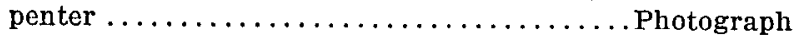

Major and Addtl. Paymaster U. S. Vols. William

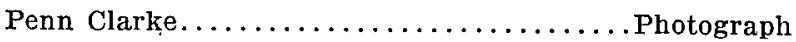

Major and Surg. U. S. Vols. Milton B. Cochran...Photograph Major and Addtl. Paymaster U. S. Vols. George

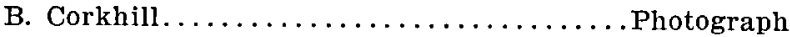

Surg. U. S. Vols. Samuel B. Davis............ Photograph

Major and Surg. Philip Harvey............ Photograph

Major and Surg. U. S. Vols. George M. Kellogg... Photograph

Capt. and Asst. Adjt. Gen. U. S. Vols. Oliver D.

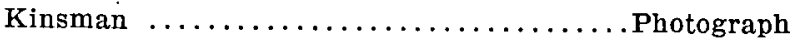

Major, 9th Regt. Vt. Res, Corps, Robert M.

- Littler ...................... Photograph 
Major and Surg. U. S. Vols. Frederick Lloyd.... Photograph Major and Surg. U. S. Vols. Benjamin McCluer..Photograph Capt. and Asst. Qr. Mr. U. S. Vols. Leander C.

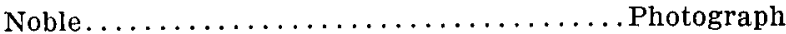

Capt. and Asst. Qr. Mr. U. S. Vols. Charles Par-

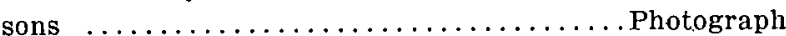

Capt. and Com. Sub. U. S. Vols. John L. Paxon... Photograph

Major and Asst. Adjt. Gen. U. S. Vols. James B.

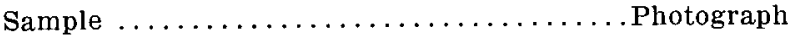

Major and Paymaster U. S. Vols. Thomas J.

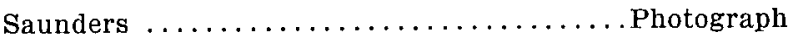

Capt. and Co. Sub. U. S. Vols. Alvanus W. Shel-

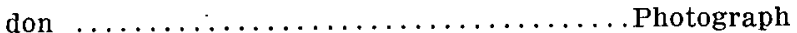

Major and Addtl. Paymaster U. S. Vols. Robert

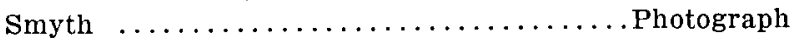

Major and Addtl. Paymaster U. S. Vols. Thaddeus

H. Stanton, as Col. and Asst. Paymaster Gen-

eral, U. S. Army .................... Photograph

Capt. and Asst. Adjt. Gen. U. S. Vols. Joseph C.

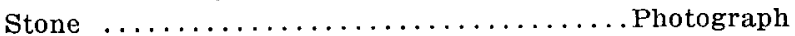

Capt. and Asst. Adjt. Gen. U. S. Vols. Samuel L.

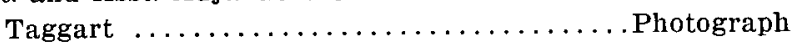

Major and Surg. U. S. Vols. Robert R. Taylor.... Photograph

Major and Surg. U. S. Vols. William Watson....Photograph

\section{'TO CLAIM JUMPERS.}

The undersigned takes this method to inform the public that in the summer of 1836 , and the spring of 1837 , he laid claim to the southeast quarter of section 15 , and the northeast quarter of section 22, in township 78 north, range 4 east. All of, which he still holds in possession, and has put on the same all the improvements required by law. This is therefore to forbid all persons entering or trespassing upon said claim under the penalty of the law, and of having their names held up to public gaze.

Royal C. Gilman,

Crow creek, Scott co.

Iowa, June 12, $1839 \quad 6 \mathrm{~m}$

-Iowa Sun, Davenport, I. T., Nov. 13, 1839. 
Copyright of Annals of Iowa is the property of State of Iowa, by \& through the State Historical Society of Iowa and its content may not be copied or emailed to multiple sites or posted to a listserv without the copyright holder's express written permission. However, users may print, download, or email articles for individual use. 